\title{
EDUKASI PENCEGAHAN COVID-19 PADA LANSIA DI SEI SIKAMBING B MEDAN
}

\author{
Nurlela Petra Saragih ${ }^{1}$, Kristina L Silalahi ${ }^{2}$, Karmila br Kaban ${ }^{3}$ \\ ${ }^{1,2,3}$ Universitas Prima Indonesia', Medan, Indonesia \\ ${ }^{1}$ nurlelapetrasaragih@unprimdn.ac.id, ${ }^{2}$ kristinasilalahi@unprimdn.ac.id, \\ ${ }^{3}$ karmilakaban@ymail.com
}

\begin{abstract}
ABSTRAK
COVID-19 telah menjadi masalah kesehatan di dunia sejak dinyatakan oleh WHO telah menjadi pandemic sejak 11 Maret 2020. Jumlah penderita Covid - 19 di Indonesia terus semakin meningkat. Secara global menurut data JHU CSSE COVID-19 hingga Juli 2021 bahwa kasus COVID-19 berjumlah 2,46 juta yang dinyatakan sembuh 2.02 juta dan meninggal dunia 64. 631 orang. Lansia merupakan orang yang rentan terhadap penularan Covid-19. Pencegahan penularan Covid-19 pada lansia diperlukan penekanan jumlah terpaparnya penderita Covid 19. Adapun tujuan dari pengabdian masyarakat ini adalah memberikan edukasi pencegahan COVID-19 pada lansia. Metode pengabdian masyarakat ini dengan cara sseminar, observasi dan peragaan cuci tangan pakai hand sanitizer, peragaan pakai masker dengan benar, diskusi dan evaluasi. Hasil pengabdian masyarakat menunjukkan lansia memahami dan memperagakan edukasi pencegahan Covid-19 dengan tetap melakukan mencuci tangan, memakai masker, menjaga jarak, menghindari keramaian, membatasi aktifitas. Hasil yang didapatkan setelah dilakukan edukasi lansia secara konsisten melakukan pencegahan Covid-19 dengan tetap melakukan mencuci tangan, memakai masker, menjaga jarak, menghindari keramaian, membatasi aktifitas.
\end{abstract}

Kata Kunci : Edukasi ; Pencegahan ; Covid-19, Lansia

\begin{abstract}
COVID-19 has become a health problem in the world since it was declared by the WHO to have become a pandemic since March 11, 2020. The number of Covid-19 sufferers in Indonesia continues to increase. Globally, according to JHU CSSE COVID-19 data until July 2021, the number of COVID-19 cases was 2.46 million, 2.02 million were declared cured and 64,631 people died. The elderly are people who are vulnerable to the transmission of Covid-19. Prevention of transmission of Covid-19 in the elderly requires suppression of the number of people exposed to Covid 19. The purpose of this community service is to provide education on preventing COVID-19 for the elderly. This community service method is carried out by means of seminars, observations and demonstrations of washing hands using hand sanitizers, demonstrations of wearing masks correctly, discussions and evaluations. The results of community service show that the elderly understand and demonstrate Covid-19 prevention education by continuing to wash their hands, wear masks, keep their distance, avoid crowds, and limit activities. The results obtained after educating the elderly are consistently preventing Covid-19 by continuing to wash hands, wear masks, maintain distance, avoid crowds, and limit activities.
\end{abstract}

Keywords : Education ;Prevention; Covid-19; Elderly 


\section{PENDAHULUAN}

Kasus COVID-19 di Indonesia mengalami peningkatan secara pesat sehingga memerlukan upaya komprehensif dalam penalaksanaan kasus dan upaya memutus rantai penularan virus COVID-19 (Bahtiar et al., 2021). Sejak WHO mengumumkan bahwa COVID-19 sebagai pandemi di dunia maka pemerintah Indonesia mengatakan bahwa COVID-19 sebagai bencana nasional (KemenKes_RI, 2021).

Penyebaran virus COVID-19 melalui tetesan air liur/droplet atau keluar dari hidung ketika orang yang terkonfirmasi batuk atau bersin, dan penyebaran yang begitu cepat maka pemerintah Indonesia menetapkan protokol kesehatan untuk pencegahan dan penanganan Covid-19. Protokol kesehatan tersebut untuk meningkatkan cakupan layanan di seluruh lapisan masyarakat.

Virus corona penyebab COVID-19 telah menginfeksi lebih dari jutaan penduduk dunia dan telah banyak yang meninggal dunia. Kematian paling banyak terjadi pada penderita COVID-19 berusia diatas 60 tahun ke atas dengan presentase mencapai $30 \%$. Lansia merupakan kelompok masyarakat yang cukup rentan dan terdampak dalam masalah kesehatan dan psikologis di era pandemic saat ini. Pemerintah telah mengeluarkan protocol kesehatan dimana protokol tersebut merupakan salah satu usaha pemerintah untuk menjaga lansia agar tidak terpapar virus corona dengan melakukan promosi keehatan degan edukasi. Rentannya lansia terhadap virus corona karena mengalami berbagai penurunan akibat proses penuaan, mulai dari menurunnya produksi pigmen rambut, hormone, kekenyalan kulit, massa otot, kepadatan tulang, hingga fungsi organ-organ tubuh dan sistem imun sebagai pelindung sudah terjadi penurunan (Pratiwi et al., 2021). Lansia merupakan kelompok yang memiliki tingkat risiko yang lebih tinggi untuk terkena virus corona hingga bisa membawa kematian (Siagian, 2020).

Menurut data WHO di seluruh dunia telah terkonfirmasi sebanyak 122 juta orang terinfeksi virus corona dan yang meninggal dunia sebanyak 2,69 juta orang, dan di Indonesia update data 30 Juli 2021 (Kementerian Kesehatan RI) terkonfirmasi positif sebanyak 3.372.374 orang, sembuh 2.730 .720 orang, meninggal dunia sebanyak 92.311 orang. Kematian paling banyak terjadi pada kelompok lansia.

Penelitian dalam Journal of Medical Virology menyatakan bahwa banyak orang terpapar virus corona. Secara umum penularan virus corona terjadi melalui udara, sentuhan atau jabat tangan, menyentuh permukaan benda yang terpapar dengan virus corona kemudian menyentuh wajah seperti hidung, mata, dan mulut tanpa mencuci tangan (Ji et al., 2020).

Organisasi Kesehatan Dunia merekomendasikan 7 kegiatan untuk mencegah penularan virus corona yaitu : 1) Selalu mencuci tangan dengan sabun dan air bersih atau menggunakan cairan mengandung alcohol, 2) melakukan jarak minimal 1 meter dengan orang yang batuk dan bersin,3) Hindari menyentuh wajah, 4) tutup mulut dan hidung saat batuk dan bersin, 5) Tetap di rumah jika merasa kurang sehat, 6) Jangan merokok dan melakukan aktifitas yang dapat melemahkan kinerja paru-paru, 7) Tetap menjaga jarak, hindari perjalanan yang tidak perlu dan menjahu dari keramaian (Elvianasti et al., 2021).

Berdasarkan wawancara dengan beberapa lansia mengatakan bahwa mereka belum memiliki pemahaman mengenai pencegahan COVID-19 dan lansia dalam penyampaian secara social media tidak memungkinkan untuk dilakukan karena mengalami kendala dalam penggunaan social media. Berdasarkan informasi yang yang didapat bahwa banyak lansia yang sudah terpapar Covid-19, dan menurut informasi yang didapat dari tokoh masyarakat, masyarakat belum pernah mendapatkan penyuluhan secara langsung mengenai pencegahan Covid-19.

Adapun tujuan pengabdian masyarakat ini adalah dengan memberikan edukasi 
kepada masyarakat lansia terhindar dari covid-19 dengan cara dapat menerapkan cuci tangan dengan baik dan benar, dapat memakai alat pelindung diri yaitu memakai masker dengan benar saat di luar rumah dan menjaga jarak jika berinteraksi dengan orang lain agar lansia terhindar dari infeksi virus COVID-19.

\section{METODE}

Data yang telah didapatkan dari tim survey dijadikan acuan dalam melaksanakan kegiatan edukasi pencegahan Covid-19. Edukasi pencegahan COVID-19 ini dilakukan untuk masyarakat lansia di Sei Sikambing Medan, karena jumlah lansia 50 orang sehingga edukasi perlu dilakukan karena informasi yang didapatkan masyarakat lansia secara langsung sangat minim. Permasalahan yang dapat dirumuskan adalah kurangnya pemahaman masyarakat lansia mengenai Covid-19 dan lansia merupakan kelompok rentan yang berdampak dengan COVID-19. Tujuan yang dicapai pada pengabdian masyarakat ini adalah masyarakat lansia mendapatkan edukasi dan pemahaman tentang virus COVID-19, bagaimana agar terhindar dari infeksi virus tersebut dan dapat menerapkan protokol kesehatan.

Kegiatan pertama sekali dilakukan dalam bentuk pemaparan materi dengan bentuk seminar pencegahan Covid-19, setelah selesai pemaparan materi dilakukan observasi kepada peserta lansia untuk memperagakan cara mencuci tangan dengan memberikan hand sanitizer, memakai masker, menjaga jarak, menghindari keramaian, membatasi aktifitas pada lansia setelah itu dilakukan observasi yang dilakukan peserta. Fasilitator memperagakan cara mencuci tangan dengan baik dan benar, memakai masker dengan tepat dan diikuti oleh peserta lansia secara bersama-sama. Evaluasi kegiatan pengabdian masyarakat ini peserta lansia dapat mempraktekkan cara mencuci tangan dengan baik dan benar, memakai masker dengan tepat, menjaga jarak, menghindari keramaian dan membatasi aktifitas agar terhindar dari virus COVID-19 dan melakukan tanya jawab dan diskusi sesuai materi.

\section{HASIL DAN PEMBAHASAN}

\section{Hasil Pelaksanaan}

Pelaksanaan dilakukan dengan beberapa susunan acara yang dihadiri oleh tokoh masyarakat, ketua RW, masyarakat. Setelah kata sambutan yang disampaikan oleh tokoh masyarakat acara kemudian dilanjutkan dengan presentasi seminar pencegahan Covid-19. Setelah selesai presentasi seminar dilakukan observasi melakukan cuci tangan, pemakaian masker yang benar, dan menjaga jarak. Observasi dilakukan kepada seluruh peserta sebanyak 50 orang untuk memperagakan cuci tangan. Berdasarkan observasi didapatkan cara melakukan cuci tangan dengan baik dan benar adalah $40 \%$, memakai masker $60 \%$, menjaga jarak 50\%. Pelaksanaan pemaparan materi/seminar, observasi dan praktek mencuci tangan, memakai masker dan menjaga jarak berlangsung selama 2,5 jam. Materi yang disampaikan selama penyuluhan membahas tentang pengenalan Covid-19, Jenisjenis Covid-19, bagaimana penyebaran virus COVID-19, Bagaiamana Pencegahan viruss Covid-19, Hal yang dapat dilakukan oleh masyarakat lansia untuk terhindar dari virus COVID-19 : Cara mencuci tangan dengan baik dan benar, cara memakai masker dengan baik dan benar, menjaga jarak. Pada acara selanjutnya diberi kesempatan untuk diskusi atau bertanya. Setelah selesai pemaparan materi kepada masyarakat lansia diberi 
kesempatan untuk menjawab beberapa pertanyaan mengenai : virus covid-19, penyebaran virus Covid-19, dan bagaimana cara pencegahannya. Masyarakat lansia diberi kesempatan untuk bertanya dan pertanyaan yang sangat penting dan menarik yaitu apakah cara mencuci tangan itu semua sama saja dan tidak harus seperti yang disampaikan oleh fasilitator.

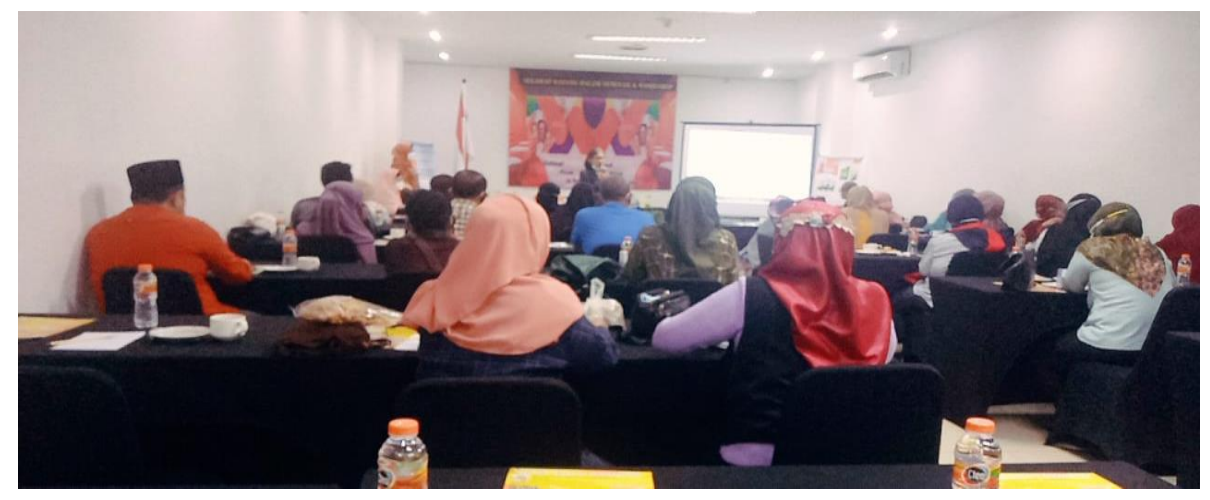

Gambar 1. Pemaparan Materi

Setelah didapatkan hasil observasi dilakukan praktek cara mencuci tangan dengan baik dan benar, cara memakai masker dan menjaga jarak. Berdasarkan hasil obsevasi setelah diedukasi dan diperagakan didapatkan hasil edukasi cara pencegahan covid-19 dengan mencuci tangan yang baik dan benar $85 \%$, cara memakai masker yang baik dan benar $90 \%$, menjaga jarak $100 \%$.

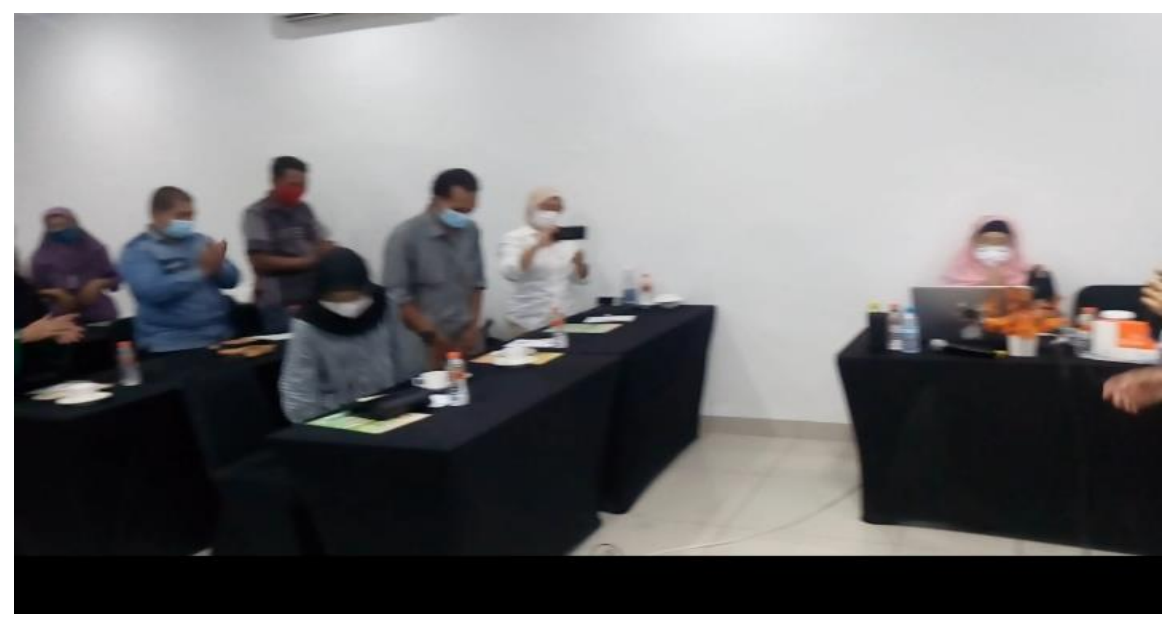

Gambar 2. Mempraktekkan cuci tangan dengan baik dan benar

\section{Pembahasan}

Dari data didapatkan peningkatan melakukan pencegahan Covid-19 dengan cara mencuci tangan dengan baik dan benar, memakai masker dengan baik dan benar serta menjaga jarak. Covid-19 merupakan pandemi yang terjadi diberbagai belahan dunia dan menjadi salah satu bentuk kekhawatiran masyarakat. Covid-19 menyebabkan penyakit yang 
menyerang system pernafasan pada manusia (Umakanthan et al., 2020). Virus Covid-19 ini telah menginfeksi jutaan orang sehingga menyebabkan kematian yang tinggi bagi penderitanya di seluruh dunia.

Gejala covid-19 pada lansia sangat bervariasi, menurut (Yuliana, 2020) setelah dilakukan observasi pada 120 lansia covid-19 ditemukan (51\%) mengalami demam, (31\%) bergejala batuk, (8\%) nyeri faring, (3\%) sesak dada dan $(2 \%)$ diare, anoreksia $(0,5 \%)$, dyspnea $((0,5 \%)$ sebagai gejala awal yang muncul.

Masyarakat memiliki peran penting dalam memutus mata rantai penularan Covid-19 agar tidak menimbulkan sumber penularan baru. Menurut (Direktorat Jenderal Kesehatan Masyarakat, 2020) untuk pencegahan Covid-19 ada beberapa tindakan yang dilakukan antara lain : tindakan pertama membersihkan tangan secara teratur dengan cuci tangan memakai sabun dan di air mengalir selama 40-60 detik atau menggunakan cairan antiseptic berbasis alcohol (hand sanitizer) minimal 20-30 detik (Larasati et al., 2020) . Hindari menyentuh mata, hidung dan mulut dengan tangan yang tidak bersih. Tindakan kedua dengan menggunakan alat pelindung diri berupa masker yang menutupi hidung dan mulut dan menerapkan etika batuk (Moudy \& Syakurah, 2020). Tindakan yang ketiga menjaga jarak minimal 1 meter dengan orang lain untuk menghindari terkena droplet dari orang yang batuk atau bersin (Kementerian Kesehatan Republik Indonesia; Gerakan Masyarakat Hidup Sehat, 2020). Tindakan selanjutnya membatasi diri terhadap interaksi atau kontak dengan orang lain yang tidak diketahui status kesehatannya, saat tiba di rumah setelah bepergian segera mandi dan berganti pakaian sebelum kontak dengan anggota keluarga yang di rumah, meningkatkan daya tahan tubuh, mengelola kesehatan jiwa dan psikososial, apabila sakit menerapkan etika batuk dan bersin (Zendrato, 2020).

Jumlah penduduk lansia di Indonesia setiap tahun semakin meningkat dan kesehatan lansia masih rendah, untuk itu pemerintah mengadakan gerakan masyarakat (GERMAS) dimana dengan gerakan masyarakat tersebut lansia mendapatkan pelayanan kesehatan. Salah satu layanan tersebut adalah dengan memberikan edukasi kepada masyarakat lansia. Dengan adanya edukasi maka diharapkan akan ada kesadaran untuk menjaga kebersihan diri dan juga mengikuti protokol kesehatan selama COVID-19.

Menurut (Hakim, 2020) dalam upaya memberikan pelindungan bagi lansia maka Negara harus mempunyai perencanaan komprehensif yang meliputi program jangka pendek dan panjang. Program jangka pendek merupakan langkah langkah cepat yang dapat dilakukan pemerintah untuk megurangi jumlah korban lansia baik dari segi kesehatan, ekonomi, maupun keamanan selama masa pandemi Covid-19. Sementara program jangka panjang adalah langkah langkah strategis untuk mempersiapkan terciptanya lansia yang tangguh, mandiri, sehat dan berkualitas. Program jangka pendek yang harus dilakukan selama masa pandemi Covid-19 adalah pemerintah secara massif memberikan pengetahuan dan pemahaman akan ancaman kesehatan, ekonomi dan keamanan dari pandemic Covid-19 dimana pendekatan strategi komunikasi terfokus menyasar kelompok lansia.

\section{KESIMPULAN DAN SARAN}

\section{Kesimpulan}

Edukasi yang dilakukan pada lansia berjalan dengan lancar dimana setelah diperagakan cara mencuci tangan, memakai masker, menjaga jarak peserta lansia dapat melakukannya/mempraktekkan pencegahan COVID-19 dengan cara mencuci tangan yang baik dan benar, mengetahui pada saat kapan memakai masker yang baik dan benar dan dapat melakukan menjaga jarak untuk mencegah terpaparnya penyakit Covid-19. Hal yang penting dari kegiatan ini adalah masyarakat lansia dapat hidup dengan sehat dan 
mandiri serta waspada terhadap virus corona.

\section{Saran}

Edukasi pencegahan Covid-19 pada lansia dapat dilakukan dengan berbagai macam cara dan satu cara yang dapat dilakukan kepada lansia adalah dengan cara melakukan praktek langsung atau diperagakan langsung bagaimana cara mencuci tangan dengan baik dan benar, memakai masker, menjaga jarak. Untuk itu keluarga, masyarakat dan petugas kesehatan lebih memperhatikan lagi metode yang efektif yang dapat dipahami dan dipraktekkan secara langsung oleh lansia untuk pencegahan COVID1-19.

\section{Referensi}

Bahtiar, H., Ariyanti, M., \& Supriyadi. (2021). ANALISIS SITUASI IPM mempunyai tiga unsur yaitu kesehatan, pendidikan yang dicapai dans tandar kehidupan ataus ering disebut ekonomi . Jadi, ketiga unsur tersebut sangat penting dalam menentukan tingkat kemampuan suatu provinsi untuk meningkatkan IPMnya. Lentera Jurnal, 1(1), 74-80. https://doi.org/10.26714/..... ...p-ISSN

Direktorat Jenderal Kesehatan Masyarakat. (2020). Panduan Kemitraan Dalam Pencegahan Covid-19.

$1-77$. https://promkes.kemkes.go.id/download/fkbr/files14425BUKU

PANDUAN KEMITRAAN COVID-19.pdf

Elvianasti, M., Roza, L., Maesaroh, M., \& Yarza, H. N. (2021). Edukasi Covid-19 Bagi Warga Lansia Di Rw 05 Kelurahan Jaticempaka Pondokgede. SELAPARANG Jurnal Pengabdian Masyarakat Berkemajuan, 4(2), 417. https://doi.org/10.31764/jpmb.v4i2.4379

Hakim, L. N. (2020). Pelindungan Lanjut Usia Pada Masa Pandemi Covid-19. Perlindungan Lanjut Usia Pada Masa Pandemi Covid-19, XII, 13-18. http://berkas.dpr.go.id/puslit/files/info_singkat/Info Singkat-XII-10-II-P3DI-Mei2020-243.pdf

Ji, W., Wang, W., Zhao, X., Zai, J., \& Li, X. (2020). Cross-species transmission of the newly identified coronavirus 2019-nCoV. Journal of Medical Virology, 92(4), 433440. https://doi.org/10.1002/jmv.25682

KemenKes_RI. (2021). Tata Laksana. KKBI Daring, 106. https://kbbi.kemdikbud.go.id/entri/Tata Laksana

Kementerian Kesehatan Republik Indonesia; Gerakan Masyarakat Hidup Sehat. (2020). Apa Yang Harus Dilakukan Masyarakat Untuk Cegah Penularan Covid-19. 2020, 124.

Larasati, A. L., Gozali, D., \& Haribowo, C. (2020). Penggunaan Desinfektan dan Antiseptik Pada Pencegahan Penularan Covid-19 di Masyarakat. Majalah Farmasetika, 5(3), 137-145. https://doi.org/10.24198/mfarmasetika.v5i3.27066

Moudy, J., \& Syakurah, R. A. (2020). Pengetahuan terkait usaha pencegahan Coronavirus Disease (COVID-19) di Indonesia. Higeia Journal of Public Health Research and Development, 4(3), 333-346.

Pratiwi, D., Suryaman, R., Putra, P., Pratiwi, R. D., Publik, P. A., Administrasi, P., \& Sakit, R. (2021). Edukasi Perilaku Hidup Bersih Dan Sehat Dalam Pencegahan Covid-19. 2(2), 249-257. 
Siagian, T. H. (2020). Corona Dengan Discourse Network Analysis. Jurnal Kebijakan Kesehatan Indonesia, 09(02), 98-106.

Umakanthan, S., Sahu, P., Ranade, A. V., Bukelo, M. M., Rao, J. S., Abrahao-Machado, L. F., Dahal, S., Kumar, H., \& Kv, D. (2020). Origin, transmission, diagnosis and management of coronavirus disease 2019 (COVID-19). Postgraduate Medical Journal, 96(1142), 753-758. https://doi.org/10.1136/postgradmedj-2020-138234

Yuliana. (2020). Wellness and Healthy Magazine. Parque de Los Afectos. Jóvenes Que Cuentan, 2(February), 124-137.

Zendrato, W. (2020). Gerakan Mencegah Daripada Mengobati Terhadap Pandemi Covid19. Jurnal Education and Development, 8(2), 242-248. 